\title{
Effect of Fly Ash and Recycled Coarse Aggregate in Concrete
}

\author{
Nithyambigai .G, P.M.Rameshwaran, Stella Mary .F* \\ Assistant Professor (Sr.G), SRM Institute of Science \& Technology, Ramapuram, Chennai
}

*Corresponding Author: Stella Mary .F, Assistant Professor (Sr.G), SRM Institute of Science \& Technology, Ramapuram, Chennai, India

\begin{abstract}
Concrete industry, utilizes 12.6 billion tons of crude materials every year. It's the biggest uses of natural resources in the world. The natural effect of creation of crude elements of cement, (for example, concrete, coarse and fine total) is extensive. The size of issues makes it common sense to examine different wellsprings of crude materials so as to diminish the utilization of energy and accessible regular assets. In the current study, the properties of concrete, when the Natural Coarse Aggregate (NCA) is partially replaced by $30 \%$ Recycled Coarse Aggregate (RCA) and cement is partially replaced by fly ash in 10\%, 20\% and 30\% with various w/b proportions as $0.38,0.40$ and 0.42 are studied. Specimens are casted with natural, recycled coarse aggregate and to be tried after a curing time of 7, 14 and 28 days. The examination was conveyed for workability and Compressive strength test. The utilization of RCA in concrete is another scope of potential reuse of materials in the construction industry.
\end{abstract}

Keywords: Fly ash, Recycled coarse aggregate, Natural coarse aggregate, w/c ratio

\section{INTRODUCTION}

Concrete is the main construction material utilized generally over the world in a wide range of designing works, it assumes a significant part in shaping our current circumstance and manageability of construction industry. The concrete industry utilizes 12.6 billion tons of raw materials every year. It's the world's most broadly utilized construction materials.

When a structure is demolished after its utilization, for fixes or decay it produces huge measure of C\&D squander, which routinely and work today is utilized for land filling. Lately, the recyclable possible development and destruction squander has made it an objective of interest and the primary focal point of waste administration arrangements on empowering minimization, recycle, reusing, and valorisation of waste instead of its last removal in landfills. In the most recent decade, construction industry has been directed using the by-products in concrete.

\section{MATERIAL Properties}

\subsection{Fine Aggregate (FA)}

The FA utilized for this project are locally obtained and belonged to zone II. The FA is sieved through $4.75 \mathrm{~mm}$ sieve first, to eliminate particles more prominent than $4.75 \mathrm{~mm}$. The FA are tested according to IS specification. Properties of the FA utilized in the project are as shown in Table-1.

Table1. Fine Aggregate

\begin{tabular}{|c|c|c|}
\hline S.No & Parameters & Values \\
\hline 1 & Specific Gravity & 2.56 \\
\hline 2 & Water Absorption & $1.0 \%$ \\
\hline 3 & Fineness Modulus & 3.10 \\
\hline
\end{tabular}

\subsection{Coarse Aggregate (CA)}

CA utilized in this work are locally available resources. CA which are passing through $20 \mathrm{~mm}$ sieve and retained on $4.75 \mathrm{~mm}$ were used and according to IS Specification. The values of different tests on CA are as shown in Table 2. 
Table2. Coarse Aggregate

\begin{tabular}{|c|c|c|}
\hline S.No & Parameters & Value \\
\hline 1 & Specific Gravity & 2.71 \\
\hline 2 & Water Absorption & $0.6 \%$ \\
\hline
\end{tabular}

\subsection{Cement}

The cement used in this work is 53 Grade OPC. The basic properties are tested as in Table- 3 .

Table3. Cement

\begin{tabular}{|c|c|c|}
\hline S.No & Parameters & Value \\
\hline 1 & Specific Gravity & 3.17 \\
\hline 2 & Normal Consistency & 31 \\
\hline 3 & Initial and final Setting Time & $41 \& 590$ \\
\hline
\end{tabular}

\subsection{Recycled Coarse Aggregate}

Unwanted concrete and brick are crushed and separated into recycled aggregate. Aggregate normally make around $55 \%$ to $70 \%$ of the capacity of a concrete mixture. The C\&D waste is mainly due to huge amount of demolition's, lack of dumbing spots, rise in shipping and clearance cost. From the test results, the specific gravity of the RCA is 2.85 .

\subsection{Fly Ash}

Fly ash particles are almost spherical in shape, which makes the concrete to flow and blend easily in mixtures. Fly Ash properties are given in Table 4.

Table4. Fly Ash

\begin{tabular}{|c|c|c|}
\hline S.No & Parameters & Values \\
\hline 1 & Density $\left(\mathrm{g} / \mathrm{cm}^{3}\right)$ & 2.15 \\
\hline 2 & Specific Gravity & 2.25 \\
\hline
\end{tabular}

\section{Experimental Program}

In this project RCA is replaced with $30 \%$ of the natural coarse aggregate and fly ash replaced with cement in $10 \%, 20 \%, 30 \% \& 40 \%$ for the water/binder ratio of $0.38,0.4$ and 0.42 . For all variations 9 numbers of cube are casted for compressive strength test at $7^{\text {th }}, 14^{\text {th }}$ and $28^{\text {th }}$ days. Mixing, casting and curing are as shown in figure 1.
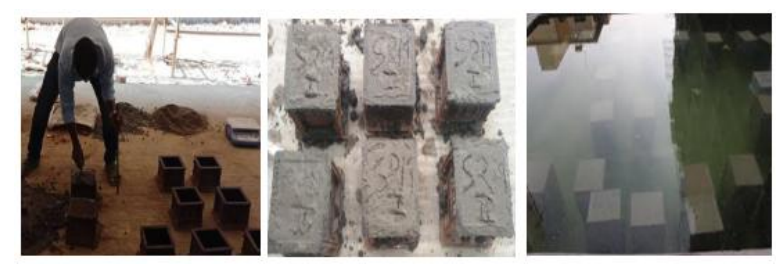

Figure1. Mixing, casting and curing

\section{RESUlt AND DISCUSSIONS}

The specimens are tested for compressive strength at various days and the test set-up in figure 2 . The tests values are as shown in Table 5 and the graphs are drawn for compressive strength, w/b ratio, $\%$ of RCA and \% of Fly ash respectively as shown in Figure 2.

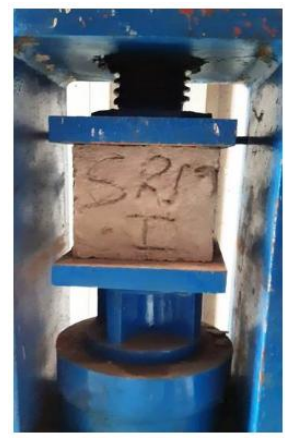

Figure2. Compressive strength 
The compressive strength of 7 days, 14 days \& 28 days result observed, with $30 \%$ of Recycled coarse aggregate replaced for natural coarse aggregate, with fly ash replacement about $10 \%, 20 \%, 30 \%$ in cement, with varying water cement ratio of $0.38,0.4,0.42$.

Table5. Compressive Strength at 7, 14 \& 28 days

\begin{tabular}{|c|c|c|c|c|c|c|}
\hline \multirow{2}{*}{$\begin{array}{l}\text { Mix } \\
\text { Type }\end{array}$} & \multirow{2}{*}{$\begin{array}{l}\% \text { of } \\
\text { RCA }\end{array}$} & \multirow[t]{2}{*}{$\mathbf{w} / \mathbf{b}$} & \multirow{2}{*}{$\begin{array}{l}\text { Fly Ash } \\
\text { in }(\%)\end{array}$} & \multicolumn{3}{|c|}{$\begin{array}{c}\text { Compression Strength in } \\
\text { MPa }\end{array}$} \\
\hline & & & & 7 days & 14 days & 28 days \\
\hline \multirow{4}{*}{ Mix - 1} & \multirow{4}{*}{30} & \multirow{4}{*}{0.38} & 0 & 30.8 & 37.2 & 47.77 \\
\hline & & & 10 & 31.2 & 38.1 & 48.8 \\
\hline & & & 20 & 31.1 & 38 & 48.9 \\
\hline & & & 30 & 30.8 & 37.8 & 47.2 \\
\hline \multirow{4}{*}{ Mix - 2} & \multirow{4}{*}{30} & \multirow{4}{*}{0.40} & 0 & 28.82 & 33.26 & 42.65 \\
\hline & & & 10 & 28.24 & 33.8 & 42.8 \\
\hline & & & 20 & 21.95 & 34.3 & 42.9 \\
\hline & & & 30 & 21 & 31.58 & 41 \\
\hline \multirow{4}{*}{ Mix - 3} & \multirow{4}{*}{30} & \multirow{4}{*}{0.42} & 0 & 25.89 & 32.5 & 41.12 \\
\hline & & & 10 & 28.2 & 32.8 & 41.22 \\
\hline & & & 20 & 28.6 & 32.8 & 41.25 \\
\hline & & & 30 & 24.85 & 30.6 & 38.36 \\
\hline
\end{tabular}

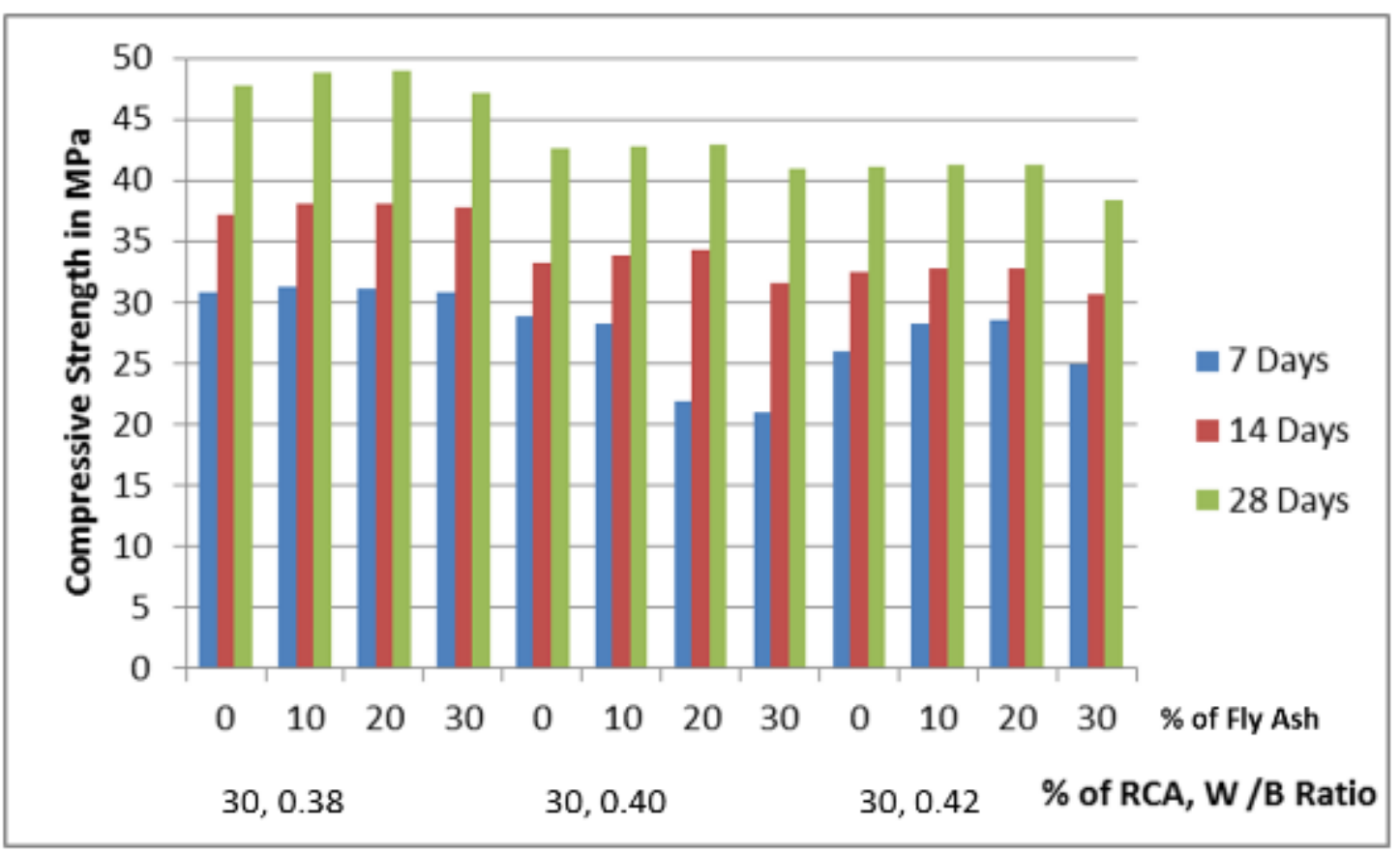

Figure3. Compressive strength for various \% of RCA and fly ash

\section{CONCLUSION}

In the Mix -1, 28 days strength of concrete performed well and achieved higher compressive strength and replacement of fly ash above $20 \%$ shows reduced compression strength than the control concrete.

In the Mix $-2 \& 3$ also show the increase in compression strength with $20 \%$ fly ash with cement and $30 \%$ replacement shows reduced strength then the control concrete.

From the above results it is that the optimum level of cement replacement was found to be $20 \%$ of Fly ash. 


\section{REFERENCES}

[1] Ravindra K. Dhir OBE, Chao Qun Lye, "Recycled Aggregate Concrete"(2019), Sustainable Construction Materials, Woodhead Publishing Series in Civil and Structural Engineering, Pages 365-418.

[2] Ravindra K.Dhir OBE, Jorgede Brito, Rui V.Silva. Chao Qun Lye, "Properties and Composition of Recycled Aggregates"(2019), Sustainable Construction Materials, Woodhead Publishing Series in Civil and Structural Engineering, Pages 89-141.

[3] F.Buyle-Bodin, R. Hadjieva-Zaharieva "Influence of industrially produced recycled aggregates on flow properties of concrete" (2002), Materials journal, Vol-35, pp- 504-509.

[4] L. Javier Malvar and Lary R.Lenke "Efficiency of Fly Ash in Mitigating Alkali- Silica Reaction Based on Chemical Composition” (2006), Materials journal, Vol-i103, No.5, pp- 319-326.

[5] Nik. D. Oikonomou "Recycled concrete aggregates" (2005), Cement and Concrete Research, Vol 27, pp315-318.

[6] Salomon M. Levy and Paulo Helene "Durability of recycled aggregates concrete: a safe way to sustainable development” (2004) Cement and Concrete Research, Vol 34, No.10, pp-1975-1980.

[7] Shi Cong Kou, Chi Sun Poon and Dixon Chan "Influence of fly ash as a cement addition on the hardened properties of recycled aggregate concrete" (2007), Materials journal, Vol- 41, No.5, pp- 1191-1201.

[8] IS: 383-1970, "Specification for coarse and fine aggregate from natural sources for concrete", Bureau of Indian Standards, New Delhi.

[9] IS: 456 - 2000 "Code of Practice for plain reinforced Concrete", Bureau of Indian Standards", New Delhi.

[10] IS 516-1959 "Method of test for strength of concrete" Bureau of Indian Standards. New Delhi.

[11] Shetty, M.S “Concrete technology theory and practice", S.Chand and Company.

Citation: Nithyambigai .G, P.M.Rameshwaran, Stella Mary .F, "Effect of Fly Ash and Recycled Coarse Aggregate in Concrete”, International Journal of Constructive Research in Civil Engineering, 6(4), pp. 14-17 DOI: https:// doi.org/10.20431/2454-8693.0604003.

Copyright: (c) 2020 Authors, this is an open-access article distributed under the terms of the Creative Commons Attribution License, which permits unrestricted use, distribution, and reproduction in any medium, provided the original author and source are credited. 